\title{
WATER BALANCE AND HEAT FLOW OF THE ARCTIC OCEAN*
}

\author{
Eberhard Vowinckel and Svenn Orvigł
}

\section{Introduction}

The present paper forms part of a study of the heat balance of the Arctic. It became necessary in this investigation to examine the existing literature on the water balance and heat flux into the Arctic Ocean.

The investigation was undertaken for heat balance calculations and not for oceanographic purposes and all the more detailed oceanographic material was disregarded, such as different water masses and stratification. However, much of this can be found in the literature cited.

When calculating the heat content of the various water masses the specific heat of the water has been taken as $1 \mathrm{cal} / \mathrm{g}$./degree and the density as $1 \mathrm{~g} . / \mathrm{cm} .^{3}$. In reality, the specific heat of Arctic Ocean water is closer to $0.94 \mathrm{cal} . / \mathrm{g} . / \mathrm{degree}$ and the density $1.03 \mathrm{~g} . / \mathrm{cm} .{ }^{3}$. As the available information on mass transport and water temperature is sporadic and not accurate in detail it was considered satisfactory to use for the present the more convenient values. The inaccuracy will amount to about 3 per cent.

In the oceanographic literature two boundaries are used for the Arctic Ocean:

1. As used by Sverdrup et al. (1954): Eurasian coast - Bering Strait coast of North American continent (excluding Hudson Bay) - coast of Greenland - Denmark Strait - Shetland Islands - Norway. The area delimited by this boundary is $14,090,000 \mathrm{~km} .{ }^{2}$.

2. As frequently used by Russian authors: mainly as under (1), but from Greenland east to Spitsbergen - north end of Novaya Zemlya - east coast of Novaya Zemlya to mainland. The area thus defined amounts to $9,906,000 \mathrm{~km} .{ }^{2}$. To avoid confusion, this area will in the following be called "Polar Ocean".

The Polar Ocean therefore comprises the Arctic Ocean less the Norwegian Sea $\left(2,705,000 \mathrm{~km} .{ }^{2}\right)$ and Barents Sea $\left(1,479,000 \mathrm{~km} .{ }^{2}\right)$.

*The research reported in this paper was sponsored in part by the Geophysics Research Directorate, U.S. Air Force Cambridge Research Laboratories, under Contract AF 19 (604)-7415.

†Department of Meteorology, McGill University, Montreal, P.Q. Canada. 


\section{Method of calculation}

The general method for the calculation of energy obtained or released by the ocean is to observe the energy influx and efflux for a given area. For this purpose the temperature and velocity profile to the sea floor must be known. If these elements were given for a sufficient number of ocean stations, maps could be constructed and for each desired area the energy balance could be obtained. However, observations are far from sufficient for such an undertaking. Especially velocity observations or calculations are lacking. The available data permit the best statements to be made about influx and efflux through the relatively narrow straits.

The Arctic Ocean has in this respect rather favourable conditions as it is a mediterranean ocean bordered by continents and has relatively narrow connections with other oceans. Furthermore, a subdivision between Arctic and Polar oceans is possible. About the interior of the Arctic Basin and its marginal seas very little can be said so far with reasonable certainty.

The influx and efflux values and the mean temperatures are discussed individually in the following.

\section{Atlantic Ocean}

The warm current entering from the Atlantic Ocean is by far the most important source as far as water volume and heat is concerned. The main part of this water flows through the Faeroes-Shetland Channel, and only minor parts between Faeroes and Iceland and, as the Irminger Current, on the west side of Iceland. Unfortunately, observations and estimates about this most important current are highly contradictory.

Sverdrup et al. (1954), when giving a water balance for the Arctic Ocean, consider only the waters entering the Arctic Ocean to the northwest of Shetland, group together all net inflow under this heading, and obtain 3.0. $\times$ $10^{6} \mathrm{~m} .{ }^{3} / \mathrm{sec}$. or $94,608 \mathrm{~km} .{ }^{3} /$ year. The same figure is quoted by Dunbar (1960).

Jacobsen (1943) studied the flux through the Faeroes-Shetland Channel along two sections with 24 individual crossings during 1902-1939. His result for the period May-September is 15.2 or $11.9 \mathrm{~km} .3 / \mathrm{hr}$, depending on the method of calculation used $(133,000$ or $104,000 \mathrm{~km} .3 /$ year $)$.

More recent is the investigation by Tait (1957), covering the years 1937-1952. From his results, the yearly flux should be approximately 10.3 $\mathrm{km} .{ }^{3} / \mathrm{hr}$. or $90,228 \mathrm{~km} .{ }^{3} /$ year. This value is significantly smaller than Jacobsen's. If from Tait's results the maximum values are chosen (for the months with more than one year's observation), the mean flux would come to $\mathbf{1 3 . 6}$ $\mathrm{km} .^{3} / \mathrm{hr}$. or $119,136 \mathrm{~km} .^{3} /$ year. This would be in better accordance with Jacobsen's results. It must be considered, however, that Tait's calculations are probably based on better observational values from more recent years.

As mentioned above, a certain amount of atlantic water does not flow through this channel, but to the northwest of the Faeroes and to the west 
of Iceland in the Irminger Current. The amount of this flow is again estimated rather differently by the various authors. Hermann (1949) concludes that the influx into the Norwegian Sea from northwest of the Faeroes is of the same magnitude as the influx through the Shetland Channel. Tait states that this flux was found to be $1 / 4$ of the channel flux, four times in 1949 and once in 1950. Other instances, with fluxes outside the channel even reaching the same value as the channel flux itself, are recorded for 1951 and 1952. No systematic investigations of this matter are available and therefore, as a tentative assumption, it will be taken that 25 per cent of the flux in the channel are found outside of it. This would bring the total flux with Jacobsen's observations to 166,000 or $130,000 \mathrm{~km} .{ }^{3} /$ year, and with Tait's mean figure to $113,000 \mathrm{~km} .{ }^{3} /$ year.

Dietrich (1957) investigated a cross-section a little to the south, at $60^{\circ} \mathrm{N}$. He obtained for June 1955 for the region between the mid-atlantic ridge and Shetland, between surface and bottom, a net northward transport of $6.8 \times 10^{6} \mathrm{~m} .{ }^{3} / \mathrm{sec}$. or $214,445 \mathrm{~km} .{ }^{3} /$ year. A considerable proportion of this water turns westward again and merges with the East Greenland Current and therefore is not transported into the Arctic Ocean. If only the flux east of $25^{\circ} \mathrm{W}$. is considered, the northward flux will be $113,530 \mathrm{~km} .{ }^{3} /$ year. If it is further considered that the June flux is, according to Tait, about 10 per cent below the yearly average, the observations of Dietrich lie between Jacobsen's and Tait's results.

Timofeyev (1956), using Russian sources, presents the following figures:

Atlantic inflow $400,000 \mathrm{~km} .{ }^{3} /$ year

outflow 248,000 net gain 152,000

He claims that his results are a long-term average. Treshnikov (1959) estimates this net flux to be $128,500 \mathrm{~km} .{ }^{3} /$ year. Shokalskii (1933) gives the flux as $140,000 \mathrm{~km} .{ }^{3} /$ year. Timofeyev (1960), quoting different Russian authors, gives for the total flux into the Norwegian Sea as much as 213,000 $\mathrm{km} .{ }^{3} /$ year, a value far higher than all other estimates.

A large number of observations are available of the temperature of this current. Sverdrup et al. (1954), after Helland-Hansen, give a mean temperature of $8^{\circ} \mathrm{C}$. Model (1950), repeated (1955/56), basing his calculations on 1,600 observations on 160 profiles, arrives at $+7.5^{\circ}$. Jacobsen (1943) gives $+6.7^{\circ}$. Dietrich's (1957) temperature and velocity cross-sections indicated for June about $+9^{\circ}$. Unfortunately, Jacobsen's figures do not lend themselves to a calculation of the mean heat flux. Timofeyev (1960) gives the annual influx of heat into the Arctic Ocean as 1,734,000 $\times 10^{15}$ cal. With his influx figure of $213,000 \mathrm{~km} .{ }^{3} /$ year his mean temperature would be $8.1^{\circ}$, very near the values given by the other authors.

However, as the atlantic inflow is by far the largest in volume, and hence the most important in heat transport, even small differences in temperature make a significant difference to the total. The best substantiated values seem to be $+7.5^{\circ}$ and $+8.1^{\circ}$. It seems advisable at the present stage to adopt the mean between the two, i.e., $7.8^{\circ} \mathrm{C}$. 


\section{Bering Strait}

For this strait several independent investigations are available. Sverdrup et al. (1954) quote an inflow of $0.3 \times 10^{6} \mathrm{~m} .3 / \mathrm{sec}$, basing the results on observations by the U.S. Coast Guard (1936), who observed a flux of $0.88 \times$ $10^{6} \mathrm{~m} .3 / \mathrm{sec}$, after a continuous summer recording for 21 hours. Sverdrup reduced this figure drastically, as he believed that during winter the flux is much less. A further estimate originates with Zubov-Karelin (after Gordienko 1958), giving $20,000 \mathrm{~km} .{ }^{3}$ /year. This is probably based on investigations by Zubov (1948) who obtains $20,000 \mathrm{~km} .{ }^{3} /$ year or Wolkov (after Timofeyev 1960), who obtains $20-22,000 \mathrm{~km} .{ }^{3}$ /year, both figures, however, are regarded by Timofeyev as too low. Timofeyev (1960) quotes as the most reliable calculation that by Basakov, based on evaluation of data up to 1943 . He gives the following annual values for water and heat flux:

Water flux: $36,125 \mathrm{~km} .^{3}$

Heat flux : $+33,490 \times 10^{15} \mathrm{cal}$.

A further investigation, taking into account many stations with flux observations, originates with Maksimov (1944). He obtains for the summer months a flux of $4,100 \mathrm{~km} .{ }^{3} /$ month and for the winter $369,800 \mathrm{~m} .^{3} / \mathrm{sec}$. He calculates the annual flux on the assumption of summer flow for the ice-free months, an intermediate flow for the months with some ice, and a winter flow with complete ice cover. The annual inflow derived in this way is $30,354 \mathrm{~km} .^{3}$. His assumption of the dependence of the flux on the ice cover seems realistic as the bulk of the flux takes place near the surface layers.

Coachman and Barnes (1961), after discussing the Russian and more recent American observations, obtain a yearly inflow of $1 \times 10^{6} \mathrm{~m} .{ }^{3} / \mathrm{sec}$. or $31,536 \mathrm{~km} .{ }^{3} /$ year; a figure very near that of Maksimov. Treshnikov (1959), without further reference, estimates the flux again rather high as $37,500 \mathrm{~km} .^{3} /$ year.

Sverdrup et al (1954) estimate the mean heat content of the current as zero. (A negative value would indicate flow of water at a mean temperature less than $0^{\circ} \mathrm{C}$.). This seems unrealistic when consulting the surface temperature distribution and cross-sections given by Lafond (1954), with temperatures in summer in the upper $30-50 \mathrm{~m}$. of over $6^{\circ}$ and below that depth of $1^{\circ}$. When converting the heat flux figure of Basakov into temperature, a mean temperature of $4.45^{\circ}$ is obtained for September, the month with the highest temperature, and the annual mean would be $0.93^{\circ}$. These figures seem to be more in line with the actual temperature observations published so far. Mosby (1962) refers to recent measurements by G. L. Bloom in eastern Bering Strait. These unpublished data seem to indicate an average temperature for the whole cross-section of about $2^{\circ} \mathrm{C}$.

\section{Runoff}

A not insignificant source of water and heat for the Arctic Ocean is the discharge from the rivers. Timofeyev (1956) uses the figure $4,400 \mathrm{~km} .{ }^{3} /$ year, 
whereas Sverdrup et al. (1954) quote $5,000 \mathrm{~km} .{ }^{3} /$ year $\left(0.16 \times 10^{6} \mathrm{~m} .{ }^{3} / \mathrm{sec}.\right)$. Gordienko (1958) gives the significantly lower figure of $3,000 \mathrm{~km} .3 /$ year. On the American continent only the Mackenzie River is important. Estimates of the flow are made by Mackay (unpublished), giving for the summer an amount of $12,000 \mathrm{~m} .3 / \mathrm{sec}$. and for winter substantially less. Antonov (1936) studied the outflow into the Kara Sea. He found the total to be 1,000 km.3/year. (Ob 440, Yenisey 410, Tazovskaya Gulf 58, Taymyr Peninsula 47 , Baidaratskaya Gulf 13 , bays of $\mathrm{Ob}$ and Gydaiamo $32 \mathrm{~km} .^{3} /$ year.) In 1958 Antonov revised and extended his figures as follows:

$\begin{array}{lll}\text { Yenisey } & 598 & \mathrm{~km} .{ }^{3} \text { /year } \\ \text { Lena } & 511 & \text { " } \\ \text { Ob } & 430 & \text { " } \\ \text { Mackenzie } & 430 & \text { " } \\ \text { Kolyma } & 132 & \text { " }\end{array}$

For the whole continental drainage into the Arctic Ocean he gives the following results:

Northwest Scandinavia, extreme NW of USSR

European USSR, excl. Pechora

$153 \mathrm{~km} .^{3} /$ year

Siberia, incl. Pechora

$359 "$

$2,442 "$

North America, incl. Yukon

Greenland (tentative estimate)

1,053

373 "

$4,380 \mathrm{~km} \cdot 3 /$ year

From this figure has to be deducted the Yukon River with $240 \mathrm{~km}^{3}$, flowing into the Bering Sea, and the Greenland figure, as this contribution will mainly consist of ice of low temperature; this would leave an inflow of $3,767 \mathrm{~km} .^{3} /$ year.

In Antonov's results for Siberia it is interesting to compare the contribution of the major rivers $(1,671)$ with the total flow from this area $(2,442)$. It is evident that Antonov considers that a large proportion of the runoff originates in the smaller rivers.

For the $\mathrm{Ob}$ Antonov (1936) gives the amount of heat carried as $4,249 \times$ $10^{15} \mathrm{cal}$. and for the Yenisey $2,849 \times 10^{15}$ cal., which gives mean temperatures of $9.6^{\circ}$ and $7.0^{\circ}$ respectively. Both these rivers have a very large drainage area, reaching far southward into warmer regions. Lena and Mackenzie have a rather cooler drainage area, and all coastal rivers are probably colder. As no better data are available, it seems best to accept Antonov's result for $\mathrm{Ob}$ and Yenisey; for Lena and Mackenzie to use an estimated $5^{\circ}$ and for the rest of the arctic rivers $3^{\circ}$. Using Antonov's (1958) runoff values this would then lead to a heat transport of $18,413 \times 10^{15}$ cal./year.

\section{Precipitation}

The net excess precipitation must be considered as incoming water. The only estimate available is by Sverdrup et al. (1954) of $0.09 \times 10^{6} \mathrm{~m} .^{3} / \mathrm{sec}$. or $2,800 \mathrm{~km} .{ }^{3} /$ year. Precipitation figures over oceans are very uncertain, and 
this holds for arctic areas, where most of the precipitation falls as snow. As Sverdrup's estimate is small in comparison to the water transport of the large ocean currents, it seems advisable to disregard this element completely, as long as the estimates of the masses carried by the ocean currents still are of the order of several ten-thousands of $\mathrm{km} .{ }^{3} / \mathrm{year}$. Furthermore, from energy considerations the contribution of precipitation will be very small indeed, as the temperature difference between precipitation and ocean water is small.

\section{Denmark Strait}

The most important avenue for outflow from the Arctic Ocean is Denmark Strait. Sverdrup et al. (1954) give the outflow as $3.55 \times 10^{6} \mathrm{~m} .{ }^{3} / \mathrm{sec}$. or $111,953 \mathrm{~km} .{ }^{3} /$ year. Timofeyev (1956) gives details of four profiles on which his outflow values are based:

$\begin{array}{lrc}\text { Aug. } 13-17 / 29 & 11.68 \mathrm{~km} \cdot{ }^{3} / \mathrm{hr} . \\ \text { Mar. 25-28/33 } & 57.92 & " \\ \text { July } 30-31 / 33 & 2.10 & " \\ \text { Aug. 21-22/33 } & 1.64 \quad "\end{array}$

The difference between one observation and another is very great. Timofeyev uses the arithmetic mean and obtains around $161,000 \mathrm{~km} .{ }^{3} /$ year. His results, however, could as well be interpreted in other ways. If the March value is taken as the maximum, it could be argued that the minimum is in September with about $2 \mathrm{~km} .{ }^{3} / \mathrm{hr}$.; the mean would then be about $30 \mathrm{~km} \cdot{ }^{3} / \mathrm{hr}$. or $262,800 \mathrm{~km} .{ }^{3} /$ year. Or it could be assumed that the March value is excessive and the mean value should be taken as $5 \mathrm{~km} .{ }^{3} / \mathrm{hr}$. or $44,000 \mathrm{~km} .{ }^{3} /$ year. Therefore, Timofeyev's values allow for a wide variation of mean flow.

Treshnikov (1959) gives, without reference, a value similar to Timofeyev's, i.e., $162,000 \mathrm{~km} .{ }^{3} /$ year. Antonov (1958) quotes, after Chaplygin, $159,500 \mathrm{~km} .{ }^{3} /$ year, to which, according to him, has to be added $2,000 \mathrm{~km} .{ }^{3}$ of water that is carried out in the form of ice. The figures of Timofeyev, Treshnikov and Chaplygin therefore are in close accord.

The results of Dietrich (1957) can be used to estimate at least the upper limit of the water transport through Denmark Strait. He observed at $60^{\circ} \mathrm{N}$., where certainly all water passing through Denmark Strait must pass as well, but where the flow comprises in addition returning warm water masses, which have moved northwards farther to the east. He obtains in the top 1,000 $\mathrm{m}$. a southward current of $2.1 \times 10^{6} \mathrm{~m} .{ }^{3} / \mathrm{sec}$, or $66,226 \mathrm{~km} .{ }^{3} /$ year, and below that depth $7.6 \times 10^{6} \mathrm{~m} .{ }^{3} / \mathrm{sec}$., or $239,674 \mathrm{~km} .{ }^{3} /$ year.

For the temperature of this current Model (1950) quotes $+2.0^{\circ}$, Sverdrup et al. (1954) $-1.0^{\circ}$. With the cross-section given by Helland-Hansen, a mean temperature of $+1.0^{\circ}$ is obtained. Chaplygin (1959) gives the mean temperature along the whole length of the East Greenland current as follows: $\begin{array}{llllllllll}60^{\circ} \mathrm{N} & 62^{\circ} & 64^{\circ} & 66^{\circ} & 68^{\circ} & 70^{\circ} & 72^{\circ} & 74^{\circ} & 76^{\circ} & 78^{\circ}\end{array}$ $-1.12^{\circ}-1.25^{\circ}-1.37^{\circ}-1.48^{\circ}-1.59^{\circ}-1.67^{\circ}-1.71^{\circ}-1.72^{\circ}-1.72^{\circ}-1.72^{\circ}$ $80^{\circ} \mathrm{N}$. 
If the latitude of Denmark Strait is taken as $68^{\circ} \mathrm{N}$., the temperature would be $-1.6^{\circ}$. When using Dietrich's results for $60^{\circ} \mathrm{N}$. (for the upper part of the current) a mean temperature of $+0.8^{\circ}$ is obtained, when allowance is made for the different velocities. This value, referring to June and a more southerly position, is certainly too high. According to Chaplygin's crosssection this figure would have to be reduced by about $0.5^{\circ}$, which would bring the temperature to $+0.3^{\circ}$. Considering all these results, a mean temperature of between $0^{\circ}$ and $-1^{\circ}$ seems the best supported assumption for this current.

\section{Davis Strait}

The second channel carrying on outflow from the Arctic Ocean is Davis Strait. Timofeyev (1956) obtains this outflow as a residual in his general budget calculation. His figure is $31,400 \mathrm{~km} .{ }^{3} /$ year. A further estimate is published by Dunbar (1960), who gives $42,574 \mathrm{~km} .{ }^{3} /$ year. Actual observations are published by Smith (1932). The observations used extend over several years. Using his out- and in-flow figures from the Labrador Sea to Baffin Bay, the net result is $31,536 \mathrm{~km} .{ }^{3} /$ year, almost exactly the same as Timofeyev's assumption.

The efflux of heat can also be calculated from Smith's results. He gives for the West Greenland current to Baffin Bay 1,576 $\times 10^{15}$ cal./year and for the Baffin Island current $-3,784 \times 10^{15} \mathrm{cal} . / \mathrm{year}$. The net result is therefore $-2,208 \times 10^{15}$ cal./year. Bailey (1957) gives the total inflow into Baffin Bay as 0.90 to $1.90 \times 10^{6} \mathrm{~m} .{ }^{3} / \mathrm{sec}$. for 1928 and $0.67 \times 10^{6} \mathrm{~m} .{ }^{3} / \mathrm{sec}$. for 1954 , whereas Kiilerich (1939) used the value $1.4 \times 10^{6} \mathrm{~m} .{ }^{3} / \mathrm{sec}$. These values are in fair agreement with those given above.

\section{The Polar Ocean}

The Polar Ocean is separated from the rest of the Arctic Ocean by a long stretch of ocean between Novaya Zemlya and Greenland. Most authors are of the opinion that no significant flux takes place across the part of this border between Novaya Zemlya and Spitsbergen. Timofeyev (1957) completely disregards any flux east of Spitsbergen. Neither do the ocean current maps published by the British Admiralty, nor those published in Russia, nor the U.S. Hydrographic Office Atlas (1958), give any influx east of Spitsbergen. Only Zubov-Karelin (after Gordienko 1958) quote a flux of 11,000 $\mathrm{km} .{ }^{3} /$ year. It seems best to disregard, for the time being, any flux east of Spitsbergen.

\section{The Greenland-Spitsbergen border}

\section{Inflow}

Zubov-Karelin (after Gordienko 1958) give an influx of 50,000 km. ${ }^{3} /$ year for the warm current between Greenland and Spitsbergen. Timofeyev (1957) calculated the inflow for the same current to be $94,082 \mathrm{~km} .{ }^{3} /$ year on the basis of the following cross-sections: May 1933, June 1939, July 1935, August 
1934, December 1936. In 1960 Timofeyev revised these estimates and suggested $118,165 \mathrm{~km} .{ }^{3} /$ year.

As with the Atlantic inflow farther south, marked seasonal and annual variations seem to exist. Lee and Hill (1959) state that the flux of the West Spitsbergen current, in the vicinity of Bear Island, was measured 30 times in 1949-1956. The volume transport showed a maximum between January and July and a minimum between September and May. Antonov (1957), however, states that there is only one maximum (in summer) and one minimum (in winter), with the inflow varying in the proportion 2:1. Furthermore, he states that the observations indicate an inter-yearly fluctuation of 1:5, i.e., at least of the same magnitude as farther south in the FaeroeShetland Channel.

Results from Timofeyev (1957) are the only ones available for the temperature of the West Spitsbergen Current. He found the mean temperature to be $1.62^{\circ}$. Timofeyev made a detailed analysis of this current, employing temperatures and velocities for each $50 \mathrm{~m}$. interval, and in this way obtained a heat content of $214,357 \times 10^{15}$ cal./year. In a later study Timofeyev (1958) remarks that 34 per cent of this heat gain is returned southward directly by mixing of the water masses of this current with the East Greenland Current. In the authors' opinion this estimate is probably on the high side.

\section{Outflow}

The outflow of the East Greenland Current between Greenland and Spitsbergen has not been observed. From the inflow figures it is estimated by Zubov (1948), without any further reference, as $80,000 \mathrm{~km} .{ }^{3} /$ year. ZubovKarelin (after Gordienko 1958) estimate $86,000 \mathrm{~km} .{ }^{3} /$ year, disregarding however the outflow through Davis Strait in their balance. Timofeyev (1957), who also obtained the outflow from the inflow figures, gives the same as for the West Spitsbergen current, $94,000 \mathrm{~km} .{ }^{3} /$ year, evidently balancing the inflow from Bering Strait and runoff against the outflow through Davis Strait. This is in disagreement with his results for the Arctic Ocean in 1956. Timofeyev (1960) gives the inflow from the Norwegian Sea into the Polar Ocean as $118,165 \mathrm{~km} .{ }^{3} /$ year. An uncertain check is possible from the results of Dietrich (1957) at $60^{\circ} \mathrm{N}$. He obtained an exact balance of in- and out-flow from the Arctic Ocean. If this result, based on one month's observation, can be generalized it would imply two things: 1) The inflow through Bering Strait plus discharge from rivers must balance the outflow through Davis Strait. 2) Inflow in the West Spitsbergen Current must equal the outflow in the East Greenland Current plus runoff into the Norwegian and Barents seas. The latter can be calculated, after Antonov (1958), as $512 \mathrm{~km} .{ }^{3} /$ year. Under these conditions the outflow of the East Greenland Current would be 93,500 or $117,500 \mathrm{~km} .{ }^{3} /$ year, depending on which of Timofeyev's figures is accepted.

Temperature data for this current are evaluated by Timofeyev (1958). He uses data from seven temperature stations in the current, between $80^{\circ}$ and $85^{\circ} \mathrm{N}$., obtaining a mean temperature of $0.62^{\circ}$. As no detailed velocity 
profile is available for this current, he assumes the same velocity profile as for the West Spitsbergen Current. His result (in 1957) was a heat transport of $72,881 \times 10^{15}$ cal./year.

Timofeyev's temperature of $0.62^{\circ}$ may possibly be too high. His observations were not taken directly in the East Greenland Current, but in an area farther north. They are in sharp contrast to the temperature values given by Chaplygin (1959). According to the latter the temperature at $80^{\circ} \mathrm{N}$. should be $-1.72^{\circ}$. All depends, naturally, on where the main transport takes place, whether near the surface or deeper. If the width of the current is taken, with Zubov, as $200 \mathrm{~km}$. and the surface velocity, as determined from the ice drift (Zubov 1948), as $10 \mathrm{~km}$./day, on the assumption of constant velocity downward a transport of $365,000 \mathrm{~km} .{ }^{3} /$ year would result, with a mean depth of $500 \mathrm{~m}$. This figure is obviously too high. It must therefore be assumed that the bulk of the mass transport takes place near the surface. This again would indicate a mean temperature lower than that used by Timofeyev.

A further indication of a lower temperature is the mean temperature for Denmark Strait, which seems to be just above $0^{\circ}$. It can hardly be conceived that the temperature farther north is higher than in the Denmark Strait. It seems therefore that a temperature between $0^{\circ}$ and $-1^{\circ}$ would be reasonable.

When comparing the flux data of the strait between Greenland and Spitsbergen with the other in- and out-flow observations, the former seem to be considerably less reliable. Practically all figures are based on the one publication by Timofeyev, and even his investigations of the West Spitsbergen Current go only to a depth of less than $800 \mathrm{~m}$. However, from the bathymetric map presented by Burkhanov (1956) it is evident that at least one channel in this strait reaches below $1,000 \mathrm{~m}$. This means that nothing is known about the deeper current in this strait. It is therefore not known whether Timofeyev's observations, on which all further deductions about in- and out-flow are based, really cover the whole flux of the West Spitsbergen Current to the bottom.

The flux and balance calculations for the Polar Ocean must therefore, for the time being, be regarded as only approximate.

\section{Ice export}

A further heat gain for the Arctic Ocean results from the formation of ice. All ice that is not melted again but is exported from the area represents an actual heat gain for the ocean. Nazarov (1938) estimates the ice volume in the Arctic to be about $32,000 \mathrm{~km} .{ }^{3}$, the formation in winter as $13,300 \mathrm{~km} .{ }^{3}$, and the loss by melting as $12,000 \mathrm{~km} \cdot{ }^{3}$, with a resulting export of $1,300 \mathrm{~km} \cdot{ }^{3}$.

Zubov (1948) refers to an export estimate of Vize of $8,000 \mathrm{~km} .^{3}$, he himself estimates $3,000 \mathrm{~km} .{ }^{3}$. Gordienko and Laktionov (1960) give a value of 8,000 to $10,000 \mathrm{~km} .^{3}$ of ice exported across the Greenland-Spitsbergen border each year. 
All estimates are based on considerations of the width of the current, its speed and the mean thickness of ice. The latter is most often taken as $3 \mathrm{~m}$. Timofeyev (1960), quoting Gordienko-Karelin's results, gives $2.5 \mathrm{~m}$. All figures mentioned so far refer to the East Greenland Current. It would be necessary to know to which locality the different authors refer: Denmark Strait or to the strait between Greenland and Spitsbergen. Corton (1954) does not make this distinction as he compares the outflow figures of Sverdrup from Denmark Strait with those by Zubov from the Greenland-Spitsbergen boundary. Nazarov's results probably refer to Denmark Strait, Zubov's and Vize's to the Greenland-Spitsbergen border. Zubov's figures are based on a width of the ice carrying current of $200 \mathrm{~km}$. and a mean surface speed of 8-12 km./day.

Corton (1954) uses Zubov's figures for the width of the current and from Sverdrup's mass transport figures he estimates the speed as 20-25 $\mathrm{km}$./day at the surface. When using $20 \mathrm{~km}$./day he obtains a transport of $4,380 \mathrm{~km} .{ }^{3} /$ year if the current were completely ice-covered. He then assumes a cover of 80 per cent and further that only 70 per cent of this is polar ice (the rest from Greenland, etc.). Taking these percentage figures into consideration, he obtains a total export of $2,450 \mathrm{~km} .^{3}$.

Gordienko-Karelin (1945) found large fluctuations from year to year in the ice export between Greenland and Spitsbergen. As an annual average for the period 1933-1944 they give an export of $1,036,000 \mathrm{~km} .{ }^{2}$. With an average thickness of $3 \mathrm{~m}$. this would result in $3,108 \mathrm{~km} .^{3}$, with $2.5 \mathrm{~m}$. ice thickness, $2,590 \mathrm{~km} .^{3}$.

Gordienko (1958) estimates the width of the East Greenland Current between Greenland and Spitsbergen to be $500 \mathrm{~km}$., much wider than the estimates of Zubov and Corton. This estimate seems to be too large, however, as the whole distance between Greenland and Spitsbergen is less than 600 $\mathrm{km}$, and a part of this space is occupied by the West Spitsbergen Current. It seems therefore best to accept a mean width of $200 \mathrm{~km}$.

If the export of $1,036,000 \mathrm{~km} .^{2}$ of Gordienko-Karelin took place over a width of $200 \mathrm{~km}$. the mean speed, on the assumption of an ice-cover of 80 per cent, would be $17.7 \mathrm{~km}$./day, which is rather higher than Zubov's, and lower than Corton's estimates. Against these estimates stands Shirshov's (1944) statement that, based on observations from station North Pole I, the speed in this area is $5.4 \mathrm{~km}$./day, which is considerably lower than all other estimates.

Koch (1945) sums up all observations of the speed of ice drift. The speed seems to vary considerably, ranging from 8 to $32 \mathrm{~km}$./day. According to his summary it seems reasonable to accept a speed of $8 \mathrm{~km}$./day near the shore and about $22 \mathrm{~km}$./day in the outer part of the ice belt. An average speed of $15-17 \mathrm{~km}$./day seems reasonable.

Finally it must be mentioned that a much higher estimate of ice export via the East Greenland Current is made by Weaver (unpublished report). He gives a value of $12,500-18,000 \mathrm{~km}^{3} /$ year. He worked with a mean speed of $12 \mathrm{~km}$./day. This estimate appears to be considerably too high. 
At present it seems best to use the value of Gordienko-Karelin as far as the transport of ice is concerned. But Corton's statement, that a certain proportion of the ice originates in Greenland and not in the Arctic Ocean, must be examined. His figure, however, seems very high. Using the glacier discharge from Greenland as given by Bauer (1954) the following figures are obtained:

$\begin{array}{lrc}\text { North Greenland } & 10 & \mathrm{~km} .{ }^{3} / \text { year } \\ \text { West Coast } & 90 & " \\ \text { Melville Bay } & 20 & " \\ \text { East Coast } & 120 & "\end{array}$

Only a part of the North Greenland discharge will appear in the strait between Greenland and Spitsbergen. If $5 \mathrm{~km}^{3}$ is accepted, which is probably on the high side, this ice can reasonably be disregarded in comparison with the discharge from the Polar Ocean.

The figures so far worked out refer to the Greenland-Spitsbergen border. No separate calculations are available for Denmark Strait. It is, however, possible to use the width of the ice flow as given by the U.S. Hydrographic Office (1958) for the different months. Using a speed for the current of $\mathbf{1 5}$ $\mathrm{km}$./day, an ice export of 739,125 km. ${ }^{2}$ would result. As before, an ice cover of 80 per cent of the surface will be accepted. Furthermore, it will be assumed that the mean thickness of the ice in Denmark Strait is less than farther north, at the most $2 \mathrm{~m}$. With these figures an ice export of $1,180 \mathrm{~km} .{ }^{3} /$ year would result. As this figure is smaller than the flux across the GreenlandSpitsbergen border, a loss of heat takes place, and it is not necessary to make a distinction between ice originating in the Polar Ocean and in Greenland.

Weaver (unpublished) is the only author, who stresses also the importance of the ice export via Davis Strait. Weaver gives the speed of the Baffin Bay-Labrador Current as $20 \mathrm{~km}$./day; the U.S. Hydrographic Office uses 9.6 to $14.4 \mathrm{~km}$./day. As Weaver's estimate is rather high, it seems more reasonable to use $10 \mathrm{~km}$./day. Ice is present in the critical area for 10.5 months or about 310 days. If tentatively an average width of $100 \mathrm{~km}$. is assumed, the annual export would amount to $310,000 \mathrm{~km} .{ }^{2}$. On the assumption of an 80 per cent ice cover the actual export would be about 248,000 $\mathrm{km} .{ }^{2}$. From this amount has to be deducted the ice export from Greenland, which is carried by this current. According to Bauer this should amount to $115 \mathrm{~km} .^{3}$. If we assume a mean thickness of $50 \mathrm{~m}$. for this land-ice, the area will be $2,300 \mathrm{~km} .^{2}$. Thus the export of sea-ice would amount to $245,700 \mathrm{~km} .^{2}$. (Assuming an average thickness of $2 \mathrm{~m}$. the annual volume of sea-ice exported is $491 \mathrm{~km}^{3}$ ).

\section{Heat gain by ice export}

The heat gained in the Arctic by the export of ice depends on the temperature of the ice. This has a pronounced seasonal variation, as shown by all temperature profiles measured in the pack-ice (Malmgren 1933, Yakovlev 1955, Untersteiner 1961). 
Table 1a. Arctic Ocean, water flow in $\mathrm{km} .{ }^{3} /$ year.

\begin{tabular}{|c|c|c|c|c|c|c|}
\hline Source & $\begin{array}{l}\text { Bering } \\
\text { Strait }\end{array}$ & $\begin{array}{c}\text { Atlantic } \\
\text { Ocean }\end{array}$ & Runoff & $\begin{array}{l}\text { Precip- } \\
\text { itation }\end{array}$ & $\begin{array}{c}\text { Denmark } \\
\text { Strait }\end{array}$ & $\begin{array}{l}\text { Davis } \\
\text { Strait }\end{array}$ \\
\hline 1. Sverdrup & {$[9,400]$} & 94,500 & {$[5,000]$} & 2,800 & 112,000 & \\
\hline $\begin{array}{l}\text { 2. U.S. Coast Guard } \\
\text { 3. Zubov-Karelin }\end{array}$ & {$[28,000]$} & & $\ldots \ldots$ & & $\ldots \ldots$ & \\
\hline 4. Wolkov & {$[2 !, 000]$} & $\cdots \cdots$ & $\ldots \ldots$ & $\ldots \ldots$ & $\ldots \ldots$ & \\
\hline 5. Basakov & 36,000 & $\ldots \ldots$ & $\ldots \ldots$ & $\ldots \ldots$ & $\ldots \ldots$ & \\
\hline $\begin{array}{l}\text { 6. Maksimov } \\
\text { 7. Coachman }\end{array}$ & $\begin{array}{l}30,300 \\
31,500\end{array}$ & & $\ldots \ldots$ & $\ldots \ldots$ & $\ldots \ldots$ & $\ldots$ \\
\hline 8. Treshnikov & 37,500 & 128,500 & $\ldots \ldots$ & 700 & 162,000 & \\
\hline 9. Dunbar & $\ldots \ldots$ & 94,500 & $\ldots \ldots$ & $\ldots \ldots$ & & 42,500 \\
\hline 10. Jacobsen & & {$[166,000]$} & $\cdots \cdots$ & $\cdots \cdots$ & & \\
\hline 11. Tait & $\ldots$ & 113,000 & & & $\ldots \ldots$ & $\cdots$ \\
\hline 12. Dietrich & & {$[(214,500)]$} & & & {$[(240,000)]$} & \\
\hline 13. Timofeyev & & {$[213,000]$} & 4,400 & & 161,000 & \\
\hline 14. Shokalskii & & 140,000 & & & & \\
\hline $\begin{array}{l}\text { 15. Gordienko } \\
16 \text { Antonov }\end{array}$ & $\cdots \cdots$ & $\ldots \ldots$ & 3,000 & $\ldots \ldots$ & $\ldots \ldots$ & \\
\hline $\begin{array}{l}\text { 16. Antonov } \\
\text { 17. Chaplygin }\end{array}$ & & & 3,800 & & 160,000 & \\
\hline $\begin{array}{l}\text { 18. Smith } \\
\text { 19. Antonov (58) }\end{array}$ & & [010 & & & & 31,500 \\
\hline 19. Antonov (58) & 37,500 & {$[213,000]$} & & & & \\
\hline
\end{tabular}

Table 1b. Polar Ocean, water flow in $\mathrm{km} .{ }^{3} /$ year. (only values that differ from Arctic Ocean are given)

\begin{tabular}{|c|c|c|c|c|}
\hline Source & East of Spitsbergen & West of Spitsbergen & East Greenland & Runoff \\
\hline Zubov-Karelin & 11,000 & 50,000 & 86,000 & \\
\hline Timofeyev & $\ldots \ldots$ & $\begin{array}{r}117,500 \\
93,500\end{array}$ & 93,500 & \\
\hline $\begin{array}{l}\text { Zubov } \\
\text { Antonov }\end{array}$ & & 128500 & 80,000 & 3300 \\
\hline Dunbar & & 120,000 & 91,500 & (5, \\
\hline
\end{tabular}

No ice temperature profiles are available from Denmark Strait or the Greenland-Spitsbergen border. The latter is near the closed pack-ice of the Polar Ocean, an area in which the local temperature variations are relatively small. As a first approximation the temperature observations from the Polar Ocean will be taken to be representative also for the Greenland-Spitsbergen border.

The ice temperature profiles in the Polar Ocean depend both on the year of observation and the thickness of ice (Yakovlev 1955). For the present purpose, observations from Malmgren (1933) and Yakovlev (1955) have been used, the former taken in relatively thin pack-ice and the latter in a thick ice floe. Thereby an average is obtained that includes at least some of the diverse ice conditions.

The two monthly mean temperatures were averaged from the surface to a depth of $2 \mathrm{~m}$. Thereafter a linear temperature gradient was assumed, to a temperature of $-1.8^{\circ} \mathrm{C}$. at the boundary between ice and water. Mean temperatures were then calculated for the following layers: $0-10 \mathrm{~cm}$., $10-50$ $\mathrm{cm}$., 50-100 cm., 100-200 cm., $200 \mathrm{~cm}$. - water. The following monthly values 
for ice thickness were used:

\begin{tabular}{|c|c|c|c|c|c|c|c|c|c|c|c|c|}
\hline & & & & & 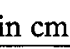 & & & & & & & \\
\hline & J. & F. & M. & A. & M. & $\mathrm{J}$. & J. & A. & S. & o. & N. & \\
\hline & 275 & 280 & 290 & 295 & 300 & 290 & 275 & 260 & 250 & 255 & 260 & \\
\hline enmark Strait & 225 & 230 & 240 & 245 & 250 & 240 & 225 & 210 & 200 & 205 & 210 & \\
\hline
\end{tabular}

It has thus been assumed that the ice thickness in Denmark Strait is $50 \mathrm{~cm}$. less than along the Greenland-Spitsbergen border. It would be very valuable to have actual observations of these thicknesses, or more accurate estimates.

Concerning ice temperatures in Denmark Strait, no estimates are available. Therefore, the mean temperatures for Angmagssalik were used as surface temperatures. These are screen temperatures and certainly higher than the surface temperatures. However, the ice of the East Greenland Current extends for a considerable distance from the coast, and the temperatures should rise toward the east. This may compensate for the use of Angmagssalik temperatures.

The temperature of the water in Denmark Strait, at the ice-water boundary, was taken as $-1.6^{\circ} \mathrm{C}$.

The following values were used for the salinity of the ice (see Untersteiner, 1961):

$0-10 \mathrm{~cm} .10-50 \mathrm{~cm} .50-100 \mathrm{~cm} .100-200 \mathrm{~cm} .200 \mathrm{~cm} .-$ water

Greenland-Spits-

bergen border

$$
\begin{array}{lllll}
0.2 \% 0 & 0.6 \% 0 & 1.5 \% 0 & 2.5 \% 0 & 3 \% 0
\end{array}
$$

Denmark Strait $\frac{0 \mathrm{~cm} .- \text { water }}{1.5^{0} / 00}$

Although many of the above values are uncertain, nevertheless with these data it is possible to obtain an estimate of the heat released by the formation and cooling of sea-ice.

Malmgren's equation for the freezing of sea-water is

$$
L=L_{p}\left(1-\frac{S_{i}}{S_{w}}\right)
$$

where $L, L_{p}$ are the latent heats of fusion of sea-ice and pure ice, and $S_{i}, S_{w}$ are the salinities of the sea-ice and sea-water.

The heat required to raise the temperature of $1 \mathrm{~cm} .^{3}$ ice is, after Untersteiner (1961):

where:

$$
\mathrm{Q}=\rho \Delta \mathrm{T}\left(0.5+\frac{4.1 \mathrm{~S}}{\mathrm{~T}_{1} \mathrm{~T}_{2}}\right)
$$

$\mathrm{Q}=$ heat required to raise the temperature of $1 \mathrm{~cm} .{ }^{3}$ ice by an amount $\Delta \mathrm{T}$ $\rho=$ density of ice: $0.913 \mathrm{~g} . / \mathrm{cm}^{3}$

$\mathrm{T}_{1}$ and $\mathrm{T}_{2}=$ ice temperatures: $\left(\mathrm{T}_{2}-\mathrm{T}_{1}=\Delta \mathrm{T}\right)$

$\mathrm{S}=$ Salinity of the ice in $\%$ 
With these formulae the amount of heat liberated by the ice layer existing in a particular month was calculated for $1 \mathrm{~cm} .{ }^{2}$ ice surface. The mean values for the year are:

$$
\begin{gathered}
\text { Greenland-Spitsbergen border } \\
\text { cal./cm. }{ }^{2} \\
21,045
\end{gathered}
$$

Denmark Strait cal./cm. ${ }^{2}$ 16,070

No reference has been found in the literature to monthly or seasonal fluctuations in ice discharge. It would seem likely that a significantly higher export takes place during summer, when the ice is less densely packed and has more freedom of movement, then in late winter when open leads refreeze almost immediately. If this reasoning were correct, the movement of the ice floe stations in the Polar Ocean should show a similar seasonal variation.

An examination of the drift data obtained on Station Alpha (Reed and Campbell, 1960) gives a mean speed for the period 1957-58 of $0.14 \mathrm{knots}=6.2$ $\mathrm{km}$./day.

Information on the drift of some of the Russian "North Pole" Stations, contained in Gordienko (1958) and Gordienko and Laktionov (1960), may be summarized as follows:

\begin{tabular}{llcc}
\hline Station & Period & Mean drift speed (true distance) \\
km./day
\end{tabular}

These figures indicate that the mean annual drift speed is about 6.3 $\mathrm{km}$./day (true distance), and that the drift varies markedly both from month to month and also from year to year. There is no indication that the summer drift is faster than the winter drift. As far as the outflow straits are concerned, there would still be the possibility that the width of the straits is diminished by land fast ice. As no observations are available of the varying 
extent of the shore ice, it is assumed that a uniform distribution of ice export during the year comes close to the actual conditions.

The heat gain by ice export is obtained by multiplying the total yearly ice export by the mean annual figure for heat release. The results are, if for Davis Strait the same heat content is used as for Denmark Strait:

$\begin{array}{lr}\text { Greenland-Spitsbergen border } 218,026 \times 10^{15} \mathrm{cal} . \\ \text { Denmark Strait } & 95,022 \times 10^{15} \mathrm{cal} . \\ \text { Davis Strait } & 39,484 \times 10^{15} \mathrm{cal} .\end{array}$

The heat gain for the Polar Ocean should therefore be $257,510 \times 10^{15}$ cal., and for the whole Arctic Ocean $134,506 \times 10^{15}$ cal., this figure being smaller as considerable melting takes place in the Norwegian Sea. The heat loss for this sea, due to melting of imported ice would be $123,004 \times 10^{15} \mathrm{cal}$.

Table 2. Arctic Ocean, water flow in $\mathrm{km} .3 /$ year.

\begin{tabular}{|c|c|c|c|c|c|}
\hline & \multicolumn{3}{|c|}{ Inflow } & \multicolumn{2}{|c|}{ Outflow } \\
\hline & Bering Strait & Atlantic Ocean & Runoff & Denmark Strait & Davis Strait \\
\hline $\begin{array}{l}\text { Maximum } \\
\text { Minimum }\end{array}$ & $\begin{array}{l}37,500 \\
30,000\end{array}$ & $\begin{array}{r}152,000 \\
94,500\end{array}$ & $\begin{array}{l}4,400 \\
3,000\end{array}$ & $\begin{array}{l}162,000 \\
112,000\end{array}$ & $\begin{array}{l}42,500 \\
31,500\end{array}$ \\
\hline \multicolumn{4}{|c|}{$\begin{array}{l}\text { 氵 Maximum } 194,000 \\
\Sigma \text { Minimum 127,500 } \\
\Sigma \text { Bering Strait }+ \text { Runoff } 42,000 \text { Maximum } \\
\text { 33,000 Minimum }\end{array}$} & \multicolumn{2}{|c|}{$\begin{array}{l}\Sigma \text { Maximum 204,500 } \\
\Sigma \text { Minimum 143,500 }\end{array}$} \\
\hline
\end{tabular}

\section{Water balance and heat flux}

After having discussed the individual currents, an attempt will now be made to arrive at a water balance and a heat flux estimate.

Tables $1 \mathrm{a}$ and $1 \mathrm{~b}$ give summaries of the different flux observations. Figures in parentheses do not apply directly to the heading of the column. Values in square brackets seem to be, according to the available evidence, definitely too high or too low and will be excluded from further consideration.

Table 2 gives those maximum and minimum values for each current that seem reasonably well established. Summation of these figures seems to show that the extreme values on the deficit side must be too high.

The last sum in Table 2 refers to the result by Dietrich mentioned above, and the inflow and outflow in the Atlantic sector seem to be balanced or very nearly so, which means that the $\Sigma$ Bering Strait + runoff must nearly balance outflow through Davis Strait. When comparing these maximum and minimum figures, the maximum for Davis Strait seems good and the minimum rather low.

This part of the balance sheet can be narrowed still further, as the runoff figure of Antonov (3,800 km. ${ }^{3} /$ year) seems to be the best and should be accepted. Of the Bering Strait figures (Table 1a), observations 5, 6 and 7 all seem well substantiated by observations and none merits preference. It seems therefore best to accept for the time being the average of these three, i.e., 32,500. If these values are accepted the outflow via Davis Strait should be taken as $36,300 \mathrm{~km} .{ }^{3} /$ year. 
Table 3a. Probable annual water and heat balance-Arctic Ocean (excluding ice).

\begin{tabular}{|c|c|c|c|}
\hline & $\mathrm{km} \cdot{ }^{3}$ & ${ }^{\circ} \mathrm{C}$. & $\mathrm{cal} . \times 10^{15}$ \\
\hline $\begin{array}{l}\text { A. Bering Strait } \\
\text { Atlantic (Russian est.) } \\
\text { Runoff }\end{array}$ & $\begin{array}{r}32,500 \\
140,000 \\
3,800\end{array}$ & \multirow{2}{*}{$\begin{array}{l}0.93 \\
7.8 \\
9.6,7 \\
5,3 \\
0,-1\end{array}$} & $\begin{array}{r}+30,225 \\
+1,092,000 \\
+18,413\end{array}$ \\
\hline Denmark Strait & 140,000 & & \multirow{2}{*}{$\begin{array}{l}0(\mathrm{a}) \\
-140,000(\mathrm{~b})^{*} \\
-2,541^{*}\end{array}$} \\
\hline Davis Strait & \multicolumn{2}{|c|}{$\begin{array}{l}36,300 \\
\Sigma \text { heat gain (a) }+1,143,000 \text { or } \\
\text { (b) }+1,283,000\end{array}$} & \\
\hline $\begin{array}{l}\text { B. Bering Strait } \\
\text { Atlantic (European est). } \\
\text { Runoff }\end{array}$ & $\begin{array}{r}32,500 \\
112,500 \\
3,800\end{array}$ & $\begin{array}{l}0.93 \\
7.8 \\
9.6,7 \\
5,3\end{array}$ & $\begin{array}{r}+30,225 \\
+877,500 \\
+18,413\end{array}$ \\
\hline Denmark Strait & 112,500 & $0,-1$ & \multirow{2}{*}{$\begin{array}{l}0(\mathrm{c}) \\
-112,500(\mathrm{~d})^{*} \\
-2,541^{*}\end{array}$} \\
\hline Davis Strait & \multicolumn{2}{|c|}{$\begin{array}{l}\Sigma \text { Heat gain }(\mathrm{c})+928,500 \text { or } \\
\text { (d) }+1,041,000\end{array}$} & \\
\hline
\end{tabular}

*Negative values in column 3 indicate flow of water at a temperature less than $0^{\circ} \mathrm{C}$.

Table 3b. Probable annual water and heat-balance-Polar Ocean (excluding ice).

\begin{tabular}{|c|c|c|c|}
\hline & $\mathrm{km} \cdot{ }^{3}$ & ${ }^{\circ} \mathrm{C}$ & cal. $\times 10^{15}$ \\
\hline $\begin{array}{l}\text { Bering Strait } \\
\text { West Spitsbergen }\end{array}$ & $\begin{array}{l}32,500 \\
93,500\end{array}$ & $\begin{array}{l}0.93 \\
1.62\end{array}$ & $\begin{array}{r}+30,225 \\
+151,470(\mathrm{e})\end{array}$ \\
\hline $\begin{array}{l}\text { Runoff } \\
\text { Davis Strait }\end{array}$ & $\begin{array}{r}117,500 \\
3,300 \\
36,300\end{array}$ & & $\begin{array}{c}+190,350(\mathrm{f}) \\
+16,100 \\
-2,541\end{array}$ \\
\hline East Greenland & $\begin{array}{c}93,500 \\
(117,500) \\
\Sigma \text { heat ga } \\
\text { (f) }+29\end{array}$ & $\begin{array}{l}-0.5 \\
247,000 \text { or }\end{array}$ & $\begin{array}{l}-46,750(\mathrm{e}) \\
(-58,750)(\mathrm{f})\end{array}$ \\
\hline
\end{tabular}

Table 3c. Probable annual heat balance, Norwegian - Barents Sea (excluding ice).

\begin{tabular}{cc}
\hline & cal. $\times 10^{15}$ \\
\hline Influx from Atlantic & $+1,092,000$ (Russian est.) \\
Influx from Polar Ocean & $+877,500$ (European est.) \\
Influx from Runoff & $-46,750$ \\
$\Sigma$ influx & $+2,300$ \\
or & $+1,047,500$ (Russian est.) \\
Efflux to Polar Ocean & $+833,000$ (European est.) \\
Efflux to Atlantic & $+151,470$ (Russian est.) \\
$\Sigma$ efflux & $-140,000$ (Rux \\
or & $+11,500$ (European est.) \\
\hline$\Sigma$ heat gain $+1,036,000 \times 10^{15}$ cal. or 24,760 cal./cm. ${ }^{2}$ (Russian est.) \\
or $+794,000 \times 10^{15}$ cal. or 18,980 cal./cm. ${ }^{2}$ (European est.) \\
\hline
\end{tabular}

A value for the Atlantic Ocean and Denmark Strait has yet to be found. Values 1 and 9 (Table 1a) for the Atlantic must be discarded, as they are below the lowest likely estimate for Denmark Strait. The value certainly has to be above 100,000 . For Denmark Strait, all Russian authors agree on a value around 160,000 . Unfortunately, the observational material on which their assumptions are based is known only for Timefeyev's results. His 
Table 4. Total heat gain and heat gain per $\mathrm{cm} .{ }^{2}$ (annual).

\begin{tabular}{|c|c|c|c|c|}
\hline & $\begin{array}{l}\text { Gain by currents } \\
\text { cal. } \times 10^{15}\end{array}$ & $\begin{array}{l}\text { Gain by ice } \\
\text { cal. } \times 10^{15}\end{array}$ & $\begin{array}{l}\text { Total heat gain } \\
\text { cal. } \times 10^{15}\end{array}$ & $\begin{array}{c}\text { Gain per cm. } \\
\text { cal. }\end{array}$ \\
\hline $\begin{array}{l}\text { A. Arctic Ocean } \\
\text { a. } \\
\text { b. } \\
\text { c. } \\
\text { d. }\end{array}$ & $\begin{array}{r}1,143,000 \\
1,283,000 \\
928,500 \\
1,041,000\end{array}$ & $\begin{array}{l}134,500 \\
134,500 \\
134,500 \\
134,500\end{array}$ & $\begin{array}{l}1,277,500 \\
1,417,500 \\
1,063,000 \\
1,175,500\end{array}$ & $\begin{array}{r}9,000 \\
10,000 \\
7,500 \\
8,500\end{array}$ \\
\hline $\begin{array}{l}\text { B. Polar Ocean } \\
\text { e. } \\
\text { f. }\end{array}$ & $\begin{array}{l}247,000 \\
298,000\end{array}$ & $\begin{array}{l}257,500 \\
257,500\end{array}$ & $\begin{array}{l}504,500 \\
555,500\end{array}$ & $\begin{array}{l}5,000 \\
5,500\end{array}$ \\
\hline \multicolumn{5}{|c|}{$\begin{array}{l}\text { a. based on Russian estimates of Atlantic flow, and a water temperature of } 0^{\circ} \mathrm{C} \text {. in } \\
\text { Denmark Strait. } \\
\text { b. as above, with a Denmark Strait water temperature of }-1^{\circ} \mathrm{C} \text {. } \\
\text { c. based on European estimates of Atlantic flow, and a water temperature of } 0^{\circ} \mathrm{C} \text {. in } \\
\text { Denmark Strait. } \\
\text { d. as above, with a Denmark Strait water temperature of }-1^{\circ} \mathrm{C} \text {. } \\
\text { e. based on West Spitsbergen current transport of } 93,500 \mathrm{~km} \cdot 3 / \text { year. } \\
\text { f. based on West Spitsbergen current transport of } 117,500 \mathrm{~km} .3 / \text { year. }\end{array}$} \\
\hline
\end{tabular}

value is, as already mentioned, to a large extent influenced by one crosssection with a high value. The Russian estimates for the Atlantic, on the other hand, are all lower than 160,000 . From the Russian results the most likely flux figure is 140,000 , whereas the most likely figure obtained from other sources would be 112,500 .

These considerations are valid as long as Dietrich's balance result is taken to be representative. On the assumption that the balance in the Atlantic Ocean need not be kept, one would probably arrive at slightly different figures.

All these possibilities are summarized in Tables 3a-c. A first glance at these tables shows remarkable differences. The main reason for these discrepancies is, in the authors' opinion, chiefly that the oceanic observations extend over short periods and are not synoptic. The great differences in the seasonal and yearly fluctuations do in fact not permit strict comparisons to be made between the different sets of observations. However, until many more simultaneous observations become available, one must try to use these figures.

When using the temperatures evaluated in the preceding paragraphs for the different currents, the mass flux figures can be transformed into heat fluxes. These are summarized in Table 4 for the Arctic and Polar oceans, and the heat gain by ice formation is also considered. From this table it will be seen that the different assumptions about the flux of Atlantic water amount to a difference of $17-20$ per cent in the heat gain per $\mathrm{cm} .{ }^{2}$ for the Arctic Ocean. Less serious is the difference in assumed water temperature, which produces a difference of about 10 per cent in the heat gain per $\mathrm{cm} .{ }^{2}$.

These differences are more important for the Arctic Ocean as a whole than for the Polar Ocean. There, about one-half of the total heat gain arises from the formation and export of ice. A wrong estimate of the ice export will be felt seriously. 


\section{References}

Antonov, N. D. 1936. Heat balance of arctic rivers. In Vize, V. and Davydov, L. K.(eds.) Degree of knowledge on the rivers of the arctic region. Leningrad, Ark. Nauchn. Inst., Trudy, Vol. 36. (In Russian).

Antonov, V. S. 1957. Basic causes for fluctuations of the amount of ice cover of arctic seas. Probl. Arkt., No. 1:41-50. (In Russian).

1958. The role of continental drainage in the current regime of the Arctic Ocean. Probl. Severa. No. 1:55-69. (In Russian).

Bailey, W. B. 1957. Oceanographic features of the Canadian Archipelago. J. Fish. Res. Bd., Can. 14:731-69.

Bauer, A. 1954. Contribution à la connaissance de l'inlandsis du Groenland. Publ. No. 39 de l'Assoc. Intern. d'Hydrol. (Ass. générale de Rome, 1954), Tome IV: 270-96.

Burkhanov, V. 1956. New Soviet discoveries in the Aretic. Moscow: Foreign languages publishing house.

Chaplygin, E. I. 1959. The waters of the East Greenland current. Probl. Arkt., No. 6:37-41. (In Russian).

Coachman, L. K. and C. A. Barnes. 1961. The contribution of Bering Sea water to the Arctic Ocean. Arctic 14:147-61.

Corton, E. L. 1954. The ice budget of the arctic pack and its application to ice forecasting. U.S. Hydrographic Office, Tech. Rept. No. 6.

Defant, A. 1936. Bericht über die ozeanographischen Untersuchungen des Vermessungsschiffs Meteor in der Dänemark Strasse und Irminger See. Sitzungsber. d. preuss. Akad. d. Wiss., Phys. Math. Klasse.

Dietrich, G. 1957. Schichtung und Zirkulation der Irminger See in Juni 1955. Ber. Deutsch. Wiss. Komm. Meeresforschung, 14:255-312.

Dunbar, M. J. 1960. Preliminary Report on Bering Strait Scheme. NCRC-60-1, Ottawa: Dept. North. Aff. and Nat. Res., 14 pp.

Gordienko, P. A. 1958. Arctic ice drift. In Arctic sea ice, Nat. Acad. of Science, Nat. Res. Council, Wash., D.C., Publ. No. 598:210-22.

(In Russian).

Gordienko, P. A. and D. B. Karelin. 1945. Problems of the movement and distribution of ice in the Arctic Basin. Probl. Arkt., No. 3. (Ref. Timofeyev, 1958).

Gordienko, P. A. and A. F. Laktionov. 1960. Principal Results of the latest oceanographic research in the Arctic Basin. Izv. Akad. Nauk SSSR, 5:22-33. (Def. Res. Bd. Can. T 350 R, 1961, 12pp.).

Helland-Hansen, B. 1934. Oceanographic observations in the northernmost part of the North Sea and southern part of the Norwegian Sea. James Johnstone Memorial Vol. Liverpool: University Press.

1936. De hydrografiske forhold ved Sydöstgrönland og i Danmark Stredet. Fiskeridirektoratets Skrifter, Ser. Havundersökelser, Bergen.

Hermann, H. 1949. Hydrographic conditions in the south-western part of the Norwegian Sea. Ann. biol., Copenhagen. 5:19-21.

Jacobsen, J. P. 1943. The Atlantic current through the Faeroe-Shetland Channel. Rap. et Procès verbaux des Réunions, Hydrography, Conseil Permanent International pour l'exploration de la mer. 112:5-48.

Kiilerich, A. B. 1939. A theoretical treatment of the hydrographical observational material. The Godthaab expedition, 1928. Medd. om Grönl., Vol. 78, 149 pp.

Koch, L. 1945. The East Greenland ice. Medd. om Grönl., Vol. 130, 373 pp.

Lafond, E. C. 1954. Physical oceanography and submarine geology of the seas to the west and north of Alaska. Arctic. 7:93-101.

Lee, A. and H. W. Hill. 1959. Seasonal variations in the flow of the Gulf stream system in relation to atmospheric circulation. Int. Ocean. Congress. Am. Assoc. Adv. Sci., pp. 805-6. 
Maksimov, I. V. 1944. Determining the relative volume of the annual flow of Pacific water into the Arctic Ocean through Bering Strait. Probl. Arkt., No. 2:51-8. (In Russian).

Malmgren, F. 1933. On the properties of sea ice. Sci. Res. Norweg. N. Pol. Exped. "Maud" (1918-25). Bergen, Vol. la, 67 pp.

Model, F. 1950. Warmwasserheizung Europas. Ber. d. D. Wetterdienstes, U.S. Zone, No. 12:51.

$-1955 / 56$. Wärmeumsatz zwischen Meer und Atmosphäre im atlantischen Südpolarmeer und im Nordpolarmeer. Ann. Meteor. No. 7(1/2):64-6.

Mosby, H. 1962. Water, salt and heat balance of the north Polar Sea and of the Norwegian Sea. Geof. Publ. Vol. 24:289-313.

Nazarov, V. S. 1938. The Arctic Ocean. Nauka i Zhizu, 5:7-9. (In Russian).

Reed, R. J. and W. J. Campbell. 1960. Theory and observation of the drift of Ice Station Alpha. Research Report, Univ. Wash., 255 pp.

Shirshov, P. P. 1944. Scientific results of the drift of station North Pole. Ak. Nauk. SSSR: 110-40. (Am. Meteor. Soc. TR 83, 1956, 51 pp.).

Shokalskii, U. M. 1933. Physical oceanography. Leningrad. (In Russian).

Smith, E. H., F. M. Soule, and O. Mosby. 1937. Marion and General Green expeditions to Davis Strait and Labrador Sea under the direction of U.S. Coast Guard. Wash. D.C., U.S. Treas. Dept., Coast Guard Bull. No. 19, 200 pp.

Sverdrup, H. U. 1950. Physical oceanography of the north Polar Sea. Arctic 3:178-86.

Sverdrup, H. U., M. W. Johnson, and R. H. Fleming. 1954. The Oceans. New York: Prentice-Hall, $1087 \mathrm{pp}$.

Sychev, K. A. 1960. The Heat content of Atlantic waters and the expenditure of heat in the Arctic Basin. Probl. Arkt., No. 3:5-15 (Am. Meteor. Soc. TR 336, 1960, 14 pp.).

Tait, J. B. 1957. Hydrography of the Faeroe-Shetland Channel 1927-52. Scottish Home Dept., Marine Res. No. 2, 309 pp.

Timofeyev, V. T. 1948. The water masses of the central zone of the Arctic Ocean. Vseso. geogr. s'ezd. Leningrad, Trudy, Vol. 2:315-20. (Am. Meteor. Soc. TR 96, 7 pp.).

1956. Annual Water balance of the Arctic Ocean. Priroda 7:89-91. (Def. Res. Bd. Can. T 338 R, 1960, 3 pp.).

1957. Atlantic water in the Arctic Basin. Probl. Arkt., No. 2:41-51. (Am. Meteor. Soc. TR 196, 13 pp.).

1958. On the age of the Atlantic waters in the Arctic Basin. Probl. Arkt., No. 5:27-31. (In Russian).

1958. An approximate determination of the heat balance of the Arctic Basin waters. Probl. Arkt., No. 4:23-8 (Am. Meteor. Soc. TR 164, 1958, 9 pp.).

1960. Water masses of the Arctic Basin. Leningrad: Hydrometeor. Izd., 1960, 190 pp. (Transl.: L. K. Coachman, Univ. Wash.: M 61-17-1961).

Treshnikov, A. F. 1959. Oceanography of the Arctic Basin. Int. Ocean. Congress 1959, Amer. Assoc. Adv. Sci., pp. 522-3.

Untersteiner, N. 1961. On the mass and heat budget of arctic sea ice. Arch. Meteor. Geoph. Biokl., Wien, Bd. 12:151-82.

U.S. Coast Guard. 1936. Report of oceanographic cruise, U.S. Coast Guard Cutter Chelan, Bering Sea and Bering Strait, 1934. Wash. D.C.

U.S. Navy Hydrographic Office. 1958. Oceanographic atlas of the polar seas. H. O. Publ. 705.

Weaver, J. C. 1948. The ice of the seas in the north of American Arctic. unpubl. manuscript for Arctic Encyclopaedia.

Yakovlev, G. N. 1955. The thermal regime of the ice cover. In Materialy nauchnoissledovatelskoi dreyfuyushchei stantsii 1950/51 goda, ed. by M. M. Somov, Leningrad, 1955, 350 pp. (Am. Meteor. Soc. TR T-RC-7, 18 pp.).

Zaicev, G. N. 1961. On the exchange of water between the Arctic Basin and the Pacific and Atlantic Oceans. Okeanologiya, 1:743-4. (Def. Res. Bd. Can. T 363 R, 1961, 2 pp.).

Zubov, N. N. 1940. The drift of the icebreaker Sedov. Nature, Vol. 145:533-9.

Zubov, N. N. 1948. Arctic ice and the warming of the Arctic. In In the centre of the Arctic. Moscow-Leningrad: 1948. (Def. Res. Bd. Can. T 14 R, 1950, 73 pp.). 